\title{
The Investment Bank's Reputation And The Price Of Underwriting Services: Evidence From China
}

\section{Yubo Li}

Division of Accounting, SHU-UTS SILC Business School, Shanghai University, JiaDing District, Shanghai, PR China

doi:10.19044/esj.2016.v12n16p498 URL:http://dx.doi.org/10.19044/esj.2016.v12n16p498

\begin{abstract}
In this paper, I examine the influence of the investment bank's reputation on the price of underwriting services of Chinese firm. Based on a sample of offers from 2004-2015, the results show that prestigious investment banks charge higher fees. Furthermore, in comparison to big firms, prestigious investment banks charge more underwriting fees for small firms. In comparison to state-owned firms, high-reputation investment banks charge higher underwriting fees for non-state-owned firms. The results indicate that the investment bank's reputation capital is different for different firms. For firms with more information problems, the reputation of investment banks is more valuable.
\end{abstract}

Keywords: Investment bank reputation, Underwriter fees, IPO, China

\section{Introduction}

In mature capital markets, the reputation of investment banks has been proven to be able to reduce the information asymmetry between financial intermediaries and investors. Furthermore, the underwriting qualities of investment banks are not directly observed by investors. Investment banks, through strict evaluation standards, help to ensure that customers do not have a negative image about them. Hence, this is with the aim of establishing its reputation. The impressively loud reputation of investment banks are used to release positive signals to the market, raising the issue of 
the likelihood of success, and reducing the cost of financing. As a result, high-reputation investment banks can obtain reputation rents as well as charge higher underwriting fees. However, this reputation premium can also encourage investment banks to maintain a higher certification quality, thereby reducing the likelihood of the emergence of lemon firms (Chemmanur \& Fulghieri, 1994; Booth \& Smith, 1986; Fang, 2005).

This notwithstanding, the reputation mechanism of investment banks may be challenged in China's capital market. There is no consensus on whether high reputation investment banks can get a reputation premium. Therefore, the following could be the reason: first of all, China's capital market is highly regulated by the central government, especially when it comes to stock. The enterprises approved by the government are able to issue shares. Also, the issue price still needs to be guided by the government. Therefore, there are questions about the influence of investment banks' reputation on the issuer's cost of capital. The premise that the issuer is willing to pay a premium for the investment bank's reputation does not exist.

Secondly, investment banks face negligible litigation risks in China. This is because the court only accepts fraud case allegations after the government has already sanctioned the issuer or the investment bank for fraud. There has never been a case of shareholder litigation against an investment bank due to IPO fraud.

Thirdly, government penalties for violations by investment banks are relatively light. China's securities regulatory authorities introduced the sponsor system form of ATM market in the UK and Hong Kong markets. Investment banks have sponsor qualification and are responsible for recommending the listed companies. They also continue to monitor the company's disclosure behavior listed within two years. If the violation occurs, the sponsor must bear some responsibility and will be punished by the regulatory authorities. Although there are investment banks which have been punished by the government because of poor sponsor quality, most of the punishment is not severe. The three months suspension issued for sponsor qualification is by far the most stringent penalties for investment banks. So given this legal and regulatory environment, it is not clear whether investment banks have sufficient incentive to provide high certification and underwriting quality service.

Consequently, we seek to shed light on whether the investment bank's 
reputation mechanism is effective and whether the reputation capital exists under the poor legal and regulatory environment. For a sample of IPO offers from 2004-2015, I discovered that high reputable investment banks match with bigger and lower leverage issuers. This indicates that loud investment banks select low risky firms in order to avoid damage to their reputation. Prestigious investment banks charge higher underwriting fees, especially for the smaller and non-state owned IPO issuers. Hence, this indicate that there is a reputation premium in Chinese IPO underwriting market. This also shows that the premium is more valuable for the high uncertainty firms.

This paper has two contributions. First, the previous evidences of the relationship between investment banks' reputation and underwriting fees are mainly from developed financial markets. This means higher litigation risks and stringent government regulation. This paper provides the evidence of reputation capital under the low litigation risk and loose government regulation. Second, I analyzed when the reputation capital is more valuable. The results show that the smaller and non-state owned issuers give investment banks' reputation more rent. Therefore, this reflects the role of reputation in solving information problems.

Therefore, this paper proceeds as follows. In section 2, I review the relevant literature. In section 3, I specify the research design. In section 4 , I present the sample selection process and descriptive statistics. In section 5 , I report the empirical results, and conclude on this paper in section 6 .

\section{Related Literature}

Chemmanur \& Fulghieri (1994) modeled reputation acquisition by investment banks in equity market. They showed that investment banks' reputation is established by adopting stringent evaluation standards. In equilibrium, high-reputation investment banks underwrite less-risk firms and receive higher compensation. Booth \& Smith (1986) argued that investment banks' reputation acts as a bonding mechanism which can reduce the information asymmetry between the intermediary and the investor.

For sample of IPO offers during 1980-1983, James (1992) showed that reputable investment banks charge lower underwriting fees. Fang (2005) examined the relationship between investment banks' reputation and the price and quality of bond underwriting services. After controlling the 
endogeneity in issuer and underwriter choice, the results showed that reputable investment banks charge higher underwriting fees. Burch et al. (2005) examined the effects of underwriting relationships on the fees charged. The results showed that issuers' loyalty to an investment bank is associated with lower fees for common stock offers, and firms that graduate to higher-quality banks face lower fees. Yasuda (2005) examined the effect of bank relationships on the firm's underwriter choice and underwriting fees in the corporate-bond market. The results show that underwriting fees were significantly lower when there were relationships between firms and commercial banks.

Butler et al. (2009) examined the effect of political connections on the underwriting fees in municipal offers. The results showed that underwriting fees were significantly higher during a time when the underwriter made political contributions to win underwriting business.

\section{Methodology}

To examine the relationship between investment banks' reputation and the underwriting fees, the following models were estimated.

SPREAD=REPU+CENTR_INST+LNAMOT+SIZE+LEV+GROWTH+OP $\mathrm{ROA}+\mathrm{CHOPNI}+$

YEAR+IND+IB

SPREAD is the gross spread divided by the total proceeds raised.

REPU is the underwriter's reputation variables. If the investment bank's IPO business market share ranks in the top ten percent in year $\mathrm{t}-1$, the variable is equal to 1 . Otherwise, it is equal to 0 . If the estimated coefficient of the variable is significantly positive, it indicates that the high-reputation investment banks charge higher underwriting fees.

CENTR_UW: An investment bank is defined to be central government-controlled if the immediate largest shareholder of the investment bank is the Ministry of Finance or State-owned Assets Supervision and Administration Commission (SASAC). China's financial market is highly regulated by the central government. As a result, we adopt the central government holding company as an alternative to the political relationship. If the estimated coefficient of this variable is significantly positive, it indicates that the investment bank's political relationship can obtain underwriting premium.

LNAMOT is the natural logarithm of the total proceeds raised for each 
IPO issue; SYN is an indicator set to one if the offer is syndicated, and set to zero if otherwise; AGE_FIRM is the age of the IPO issuer; SIZE is the natural logarithm of firm's total assets in pre-IPO year; GROWTH is the annual sales growth rate in pre-IPO year; LEV is the total debts divided by total assets in pre-IPO year; OPROA is the annual operating income divided by the average total assets in pre-IPO year; CHOPNI is the change in operating income in IPO year divided by operating income in pre-IPO year; GEM is equal to 1 if the company applies for listing on the GEM, otherwise it is equal to 0; SMB is equal to 1 if the company is listed on the SME board market, otherwise it is equal to 0; Year is year dummy variable; IND is industry dummy variable; and IB is investment bank dummy variable.

\section{Sample Selection Process and Descriptive Statistics}

Table 1 details our sample selection procedures for IPO firms. We limit our sample to the period of 2004-2015, because the sponsor system was implemented from the beginning of 2004. Finally, we have 1322 IPO issuers. The data of this paper comes from WIND.

Table 1. Sample Selection Procedures

\begin{tabular}{lc}
\hline & Total \\
\hline Initial sample of IPO firms over the period of 2004-2015 & 1552 \\
\hline Excluding firms of underwriting fees and financial data loss & $(137)$ \\
\hline Excluding firms of actual controller data loss & $(95)$ \\
\hline Final sample & 1322 \\
\hline
\end{tabular}

Table 2 reports the descriptive statistics of the variables. The mean of spread is $6 \%$, the minimum value is $1 \%$, and the maximum value is $15 \%$. On average, $48 \%$ of issuers choose high-reputation investment banks, and $28 \%$ of firms' underwriters are controlled by the central government. $17 \%$ of issuers are state-owned firms. The mean of operating income change rate is $-78 \%$, reflecting the decline of performance of companies after IPO. $32 \%$ of IPO companies are listed on the GEM board, and 50\% of IPO companies are listed on the SMB board. Table 3 reports the Pearson correlation matrix for the regression variables. In addition, there is a significant correlation between the explanatory variables. Thus, I determined whether there was a severe multicollinearity for the regression models. 
Table 2. Descriptive statistics

\begin{tabular}{ccccccccc}
\hline Variable & $\mathrm{N}$ & mean & min & $\mathrm{p} 25$ & $\mathrm{p} 50$ & $\mathrm{p} 75$ & $\max$ & $\mathrm{sd}$ \\
\hline SPREAD & 1322 & 0.06 & 0.01 & 0.04 & 0.05 & 0.07 & 0.15 & 0.03 \\
\hline REPU & 1322 & 0.48 & 0.00 & 0.00 & 0.00 & 1.00 & 1.00 & 0.50 \\
\hline CENTR_UW & 1322 & 0.28 & 0.00 & 0.00 & 0.00 & 1.00 & 1.00 & 0.45 \\
\hline LNAMOT & 1322 & 20.28 & 18.70 & 19.60 & 20.09 & 20.66 & 24.57 & 1.05 \\
\hline SYN & 1322 & 0.04 & 0.00 & 0.00 & 0.00 & 0.00 & 1.00 & 0.19 \\
\hline SOE & 1322 & 0.17 & 0.00 & 0.00 & 0.00 & 0.00 & 1.00 & 0.38 \\
\hline AGE_FIRM & 1322 & 9.85 & -1.00 & 6.00 & 9.00 & 13.00 & 44.00 & 5.12 \\
\hline SIZE & 1322 & 20.53 & 18.58 & 19.59 & 20.14 & 20.88 & 28.17 & 1.62 \\
\hline LEV & 1322 & 0.48 & 0.08 & 0.34 & 0.47 & 0.60 & 0.96 & 0.18 \\
\hline GROWTH & 1322 & 0.25 & -0.25 & 0.08 & 0.21 & 0.36 & 1.31 & 0.26 \\
\hline OPROA & 1322 & 0.14 & 0.01 & 0.09 & 0.13 & 0.19 & 0.42 & 0.08 \\
\hline CHOPNI & 1322 & -0.78 & -57.27 & -0.81 & 0.00 & 1.03 & 28.26 & 9.25 \\
\hline GEM & 1322 & 0.32 & 0.00 & 0.00 & 0.00 & 1.00 & 1.00 & 0.46 \\
\hline SMB & 1322 & 0.50 & 0.00 & 0.00 & 0.00 & 1.00 & 1.00 & 0.50 \\
\hline
\end{tabular}


Table 3. The Pearson correlation matrix for the regression variables

\begin{tabular}{|c|c|c|c|c|c|c|c|c|c|c|c|c|}
\hline & $\begin{array}{c}\text { SPREA } \\
\text { D }\end{array}$ & REPU & $\begin{array}{c}\text { CENTR_INS } \\
\mathrm{T}\end{array}$ & $\begin{array}{l}\text { LNAMO } \\
\qquad \mathrm{T}\end{array}$ & SYN & SOE & $\begin{array}{c}\text { AGE_FIR } \\
\mathrm{M}\end{array}$ & SIZE & LEV & $\begin{array}{c}\text { GROWT } \\
\mathrm{H}\end{array}$ & $\begin{array}{c}\text { OPRO } \\
\text { A }\end{array}$ & $\begin{array}{c}\text { CHOPN } \\
\text { I }\end{array}$ \\
\hline SPREAD & 1 & & & & & & & & & & & \\
\hline REPU & 0.0262 & 1 & & & & & & & & & & \\
\hline CENTR_INS & $-0.1498^{*}$ & 0.0309 & 1 & & & & & & & & & \\
\hline \multicolumn{13}{|l|}{$\mathrm{T}$} \\
\hline LNAMOT & $-0.5776^{*}$ & 0.1162 & $0.2443^{*}$ & 1 & & & & & & & & \\
\hline SYN & $-0.2826^{*}$ & 0.0325 & $0.1924^{*}$ & $0.6392 *$ & 1 & & & & & & & \\
\hline SOE & $-0.2750 *$ & 0.0042 & $0.1991 *$ & $0.3644^{*}$ & $0.3797 *$ & 1 & & & & & & \\
\hline \multirow[t]{2}{*}{ AGE_FIRM } & $0.1704 *$ & -0.018 & -0.0149 & 0.0345 & $0.1090 *$ & -0.0477 & 1 & & & & & \\
\hline & & 2 & & & & & & & & & & \\
\hline SIZE & $-0.4170^{*}$ & 0.0606 & $0.2401 *$ & $0.8114 *$ & $0.7210 *$ & $0.4942 *$ & $0.1280 *$ & 1 & & & & \\
\hline \multirow[t]{2}{*}{ LEV } & $-0.3088^{*}$ & -0.052 & $0.0822 *$ & $0.3163^{*}$ & $0.3280^{*}$ & $0.2851 *$ & 0.0164 & $0.5640 *$ & 1 & & & \\
\hline & & 6 & & & & & & & & & & \\
\hline \multirow[t]{2}{*}{ GROWTH } & $-0.1069 *$ & 0.0288 & 0.0064 & 0.034 & -0.0484 & -0.0466 & $-0.1275^{*}$ & -0.0893 & 0.0516 & 1 & & \\
\hline & & & & & & & & $*$ & & & & \\
\hline \multirow[t]{2}{*}{ OPROA } & 0.0462 & 0.057 & -0.0335 & $-0.0741 *$ & -0.2341 & -0.2645 & $-0.0878 *$ & -0.4503 & -0.6204 & $0.2384 *$ & 1 & \\
\hline & & & & & $*$ & $*$ & & $*$ & $*$ & & & \\
\hline CHOPNI & $-0.0800^{*}$ & 0.0107 & -0.0026 & $0.0934^{*}$ & $0.0971^{*}$ & 0.0586 & -0.0515 & $0.1110^{*}$ & 0.0446 & -0.0244 & -0.0066 & 1 \\
\hline
\end{tabular}




\section{Empirical Results}

The correlation between issuer and underwriter is endogenous (Chemmanur \& Fulghieri, 1994; Fang, 2005). Before examining how investment banks affect underwriting fees, I explored the factors that explain the choice of investment bank for the IPO issuers. Understanding these factors can help identify important control variables when investigating the relationship between the investment banks' reputation and the underwriting fees. Table 4 reports the results of the factors which affect the underwriter's choice and the dependent variable of the investment banks' reputation indicator. The detailed definition of variables is consistent with section 3 . The estimated coefficient of LNAMOT is significantly positive, and the estimated coefficient of LEV is significantly negative. Hence, this indicate that high reputable investment banks are more likely to choose less risky firms.

Table 4. The determination of underwriter choice

(1)

\begin{tabular}{|c|c|}
\hline & REPU \\
\hline \multirow[t]{2}{*}{ LNAMOT } & $0.295^{* *}$ \\
\hline & $(2.55)$ \\
\hline \multirow[t]{2}{*}{ SOE } & -0.155 \\
\hline & $(-0.90)$ \\
\hline \multirow[t]{2}{*}{ AGE_FIRM } & -0.010 \\
\hline & $(-0.85)$ \\
\hline \multirow[t]{2}{*}{ SIZE } & 0.024 \\
\hline & $(0.27)$ \\
\hline \multirow[t]{2}{*}{ LEV } & $-1.181^{* * * *}$ \\
\hline & $(-2.62)$ \\
\hline \multirow[t]{2}{*}{ GROWTH } & 0.244 \\
\hline & $(1.06)$ \\
\hline \multirow[t]{2}{*}{ OPROA } & -0.165 \\
\hline & $(-0.15)$ \\
\hline \multirow[t]{2}{*}{ CHOPNI } & -0.124 \\
\hline & $(-0.84)$ \\
\hline \multirow[t]{2}{*}{ _cons } & $-5.903^{* * * *}$ \\
\hline & $(-4.81)$ \\
\hline$N$ & 1322 \\
\hline pseudo $R^{2}$ & 0.018 \\
\hline
\end{tabular}




$$
\begin{gathered}
t \text { statistics in parentheses } \\
{ }^{*} p<0.10,{ }^{* *} p<0.05,{ }^{* * *} p<0.01
\end{gathered}
$$

Table 5 reports the regression results. In models 1 and 2, the estimated coefficient of REPU is significantly positive. This indicates that the high-reputation investment banks charge higher underwriting fees. The estimated coefficient of CENTR_UW is insignificantly negative, indicating that the actual controllers of investment banks do not significantly affect the underwriting fees. The estimated coefficient of CHOPNI is significantly negative. This indicates that the underwriting fees of better performance firms are lower. As a result, the investment banks can determine the underwriting expense according to the customer's performance. The estimated coefficient of GEM is significantly positive, indicating that investment banks charge more underwriting fees for the firms listed in GEM board.

Next, I examined how the investment bank charges underwriting fees for different scale companies. Model 3 adds the cross variable of investment reputation and the firm's scale variable (REPU*SIZE). The estimated coefficient of the cross variable is significantly negative, indicating that high-reputation investment banks charge higher underwriting fees for small scale enterprises. In turn, small businesses are willing to pay more for a high reputation investment banks.

I also examined if there exists any significant difference between the state-owned and non-state owned firms in the effects of investment banks' reputation on the underwriting fees. Model 4 adds the cross variable of investment banks reputation and non-state owned variable (REPU*NSOE). The estimated coefficient of the cross variable is significantly positive, indicating that high-reputation investment banks charge more underwriting fees for non-state owned firms.

\section{Conclusion}

In this paper, I examined the relationship between the investment bank's reputation and the underwriting fees. The results show that high-reputation investment banks' charge more underwriting fees, reflecting the reputation capital of investment banks in Chinese IPO underwriting market. Next, I found that, when comparing big firms, high-reputation investment banks charge higher underwriting fees for small firms. Comparing state-owned 
firms, high-reputation investment banks charge higher underwriting fees for non-state-owned firms. The results indicate that the investment bank's reputation capital is different for different firms. For the firms with more information problems, the reputation of investment banks is more valuable.

Table 5. Regression results

\begin{tabular}{|c|c|c|c|c|}
\hline & $\begin{array}{c}(1) \\
\text { SPREAD }\end{array}$ & $\begin{array}{c}(2) \\
\text { SPREAD }\end{array}$ & $\begin{array}{c}(3) \\
\text { SPREAD }\end{array}$ & $\begin{array}{c}(4) \\
\text { SPREAD }\end{array}$ \\
\hline REPU & $\begin{array}{c}0.004^{* *} \\
(2.30)\end{array}$ & $\begin{array}{l}0.003^{*} \\
(1.80)\end{array}$ & $\begin{array}{c}0.029^{* *} \\
(2.16)\end{array}$ & $\begin{array}{l}-0.001 \\
(-0.25)\end{array}$ \\
\hline REPU*SIZE & & & $\begin{array}{c}-0.001^{* *} \\
(-1.97)\end{array}$ & \\
\hline REPU*NSOE & & & & $\begin{array}{l}0.005^{*} \\
(1.72)\end{array}$ \\
\hline CENTR_UW & & $\begin{array}{l}-0.012 \\
(-1.40)\end{array}$ & $\begin{array}{l}-0.012 \\
(-1.43)\end{array}$ & $\begin{array}{l}-0.013 \\
(-1.48)\end{array}$ \\
\hline LNAMOT & & $\begin{array}{l}-0.014^{* * *} \\
(-10.17)\end{array}$ & $\begin{array}{l}-0.014^{* * *} \\
(-10.15)\end{array}$ & $\begin{array}{l}-0.014^{* * *} \\
(-10.14)\end{array}$ \\
\hline SYN & & $\begin{array}{c}0.018^{* * *} \\
(4.33)\end{array}$ & $\begin{array}{c}0.017^{* * *} \\
(4.24)\end{array}$ & $\begin{array}{c}0.017^{* * * *} \\
(4.23)\end{array}$ \\
\hline NSOE & & $\begin{array}{l}0.001 \\
(0.47)\end{array}$ & $\begin{array}{l}0.001 \\
(0.48)\end{array}$ & $\begin{array}{l}-0.001 \\
(-0.67)\end{array}$ \\
\hline AGE_FIRM & & $\begin{array}{l}0.000 \\
(0.57)\end{array}$ & $\begin{array}{l}0.000 \\
(0.43)\end{array}$ & $\begin{array}{l}0.000 \\
(0.45)\end{array}$ \\
\hline SIZE & & $\begin{array}{l}-0.002 \\
(-1.35)\end{array}$ & $\begin{array}{l}-0.001 \\
(-0.78)\end{array}$ & $\begin{array}{l}-0.001 \\
(-1.33)\end{array}$ \\
\hline LEV & & $\begin{array}{l}0.000 \\
(0.01)\end{array}$ & $\begin{array}{l}0.000 \\
(0.05)\end{array}$ & $\begin{array}{l}-0.000 \\
(-0.02)\end{array}$ \\
\hline GROWTH & & $\begin{array}{l}-0.003 \\
(-1.45)\end{array}$ & $\begin{array}{l}-0.003 \\
(-1.46)\end{array}$ & $\begin{array}{l}-0.003 \\
(-1.50)\end{array}$ \\
\hline OPROA & & $\begin{array}{l}-0.006 \\
(-0.62)\end{array}$ & $\begin{array}{l}-0.006 \\
(-0.65)\end{array}$ & $\begin{array}{l}-0.006 \\
(-0.66)\end{array}$ \\
\hline CHOPNI & & $\begin{array}{l}-0.002^{*} \\
(-1.72)\end{array}$ & $\begin{array}{l}-0.002^{*} \\
(-1.71)\end{array}$ & $\begin{array}{l}-0.002^{*} \\
(-1.74)\end{array}$ \\
\hline GEM & & $\begin{array}{c}0.008^{* * *} \\
(3.99)\end{array}$ & $\begin{array}{c}0.008^{* * *} \\
(3.99)\end{array}$ & $\begin{array}{c}0.008^{* * * *} \\
(4.00)\end{array}$ \\
\hline SMB & & $\begin{array}{l}0.002 \\
(1.22)\end{array}$ & $\begin{array}{l}0.002 \\
(1.22)\end{array}$ & $\begin{array}{l}0.002 \\
(1.26)\end{array}$ \\
\hline
\end{tabular}




\begin{tabular}{lcccc} 
_cons & $0.051^{* *}$ & $0.338^{* * *}$ & $0.326^{* * *}$ & $0.339^{* * * *}$ \\
& $(2.07)$ & $(12.85)$ & $(12.14)$ & $(12.90)$ \\
\hline$N$ & 1322 & 1322 & 1322 & 1322 \\
$R^{2}$ & 0.495 & 0.656 & 0.657 & 0.657 \\
\hline
\end{tabular}

$t$ statistics in parentheses

$$
{ }^{*} p<0.10,{ }^{* *} p<0.05,{ }^{* * *} p<0.01
$$

\section{References:}

Butler et al. (2009). Corruption, political connection, and municipal Finance. Review of Financial Studies, 2009, 22 (7): 2873-2905.

Booth \& Smith (1986). Capital raising, underwriting, and the certification hypothesis. Journal of Financial Economics, 15, 261-281.

Chemmanur \& Fulghieri (1994). Investment bank reputation, information production, and financial intermediation. Journal of Finance 49, 57-79.

James (1992). Relationship-specific assets and the pricing of underwriter services. Journal of Finance 47, 1865-1885.

Fang (2005). Investment bank reputation and the price and quality of underwriting services. Journal of Finance, 60(6): 2729-2761.

Yasuda (2005). Do bank relationships affect the firm's underwriter choice in the corporate bond underwriting market? Journal of Finance, 60, 1259-1292. 